\title{
An investigation of organic sheep and goat production by nomad pastoralists in southern Iran
}

\author{
Hamid R. Ansari-Renani
}

\begin{abstract}
The nomadic pastoralist system in Baft district in Kerman province is well known in Iran for producing cashmere from Raeini goats. However, there is little information regarding the organic sheep and goat production systems. Interviews and field observations were carried out with 30 Siahjel nomad families of Raen origin in proximity of Baft city to characterize the organic production system in terms of feeding, animal health and veterinary treatments, husbandry management practices, transport, slaughtering and housing. Unimproved rangeland was found to be the main source of sheep and goat nutrition belonging to nomads in southern Iran. Nomad livestock were not fed in stables or in restricted areas but moved and grazed freely in extensive open grazing areas.

As a nomadic traditional feeding management practice, there were no minerals, vitamins, pro-vitamins or GMOs for animal feed. Nomad sheep and goat breeds were considered to be robust, adapted to the environment and disease-tolerant livestock. In the nomadic system, no animal cruelty practices such as tail ducking, dehorning and tethering were allowed. To keep ruminants in groups to meet their social needs, nomad families stayed and kept animals together to support each other in different livestock activities, including shepherding, feeding, milking and health care. Due to natural breeding in nomadic herds, the male breeding stock was kept and grazed separately from does during the breeding season. Nomadic livestock products, i.e. meat, milk, wool, could be labelled organic after making local studies, surveillance, regulation and certification.
\end{abstract}

Keywords: Nomad, Rangeland, Goats, Sheep, Organic products

\section{Background}

The increasing incidences of residues of pesticides, chemical fertilizers, antibiotics and hormones in livestock products overrecent years are of great concern. For ensuring food safety and protecting human health, the attitude toward organic products is rapidly gaining positive perceptions from people in developing countries including Middle Eastern countries (IFOAM 2005; Jaffee and Howard 2010; Schleenbecker and Hamm 2013; FiBL 2013).

Livestock organic production entails production of highly nutritive quality foods free from all kinds of impurities for sound human health, in which ethological characteristics of animals are respected. Organic livestock producers commit to respect a list of specifications governing animal care, welfare and feeding, obliging

Correspondence: hansarirenani@gmail.com

Animal Science Research Institute (ASRI), P.O. Box 31585-1483 Karaj, Islamic Republic of Iran

them to give their livestock access to pasture (Leroux et al. 2009) which is nutritionally favourable, as products from pasture-fed livestock have been shown to have a nutritionally more desirable composition than products from livestock fed on concentrate diets (Fisher et al. 2000; Aurousseau et al. 2004; Sante-Lhoutellier et al. 2008).

Organic sheep and goat production based on grazing (Rahmann 2002, 2014) could be a valid alternative to animals kept in intensive or industrial systems fed with standard rations of concentrates. Existing similarities between organic agricultural products and extensive farming systems in many developing countries (Ben Kheder 2001; Znaidi 2001) enable many traditional farmers, including nomads, to convert to organic systems.

The geographical and ecological conditions of Iran are well-suited to small ruminant production. The relatively low cost of sheep and goat farming (local breeds - well adapted to their environment plus extensive free 
communal grazing areas) and the increasing demand for expensive organic products in domestic and regional export markets (Herman and Steidle 2014; Steidle and Herman 2014; Ak and Koyuncu 2002) encourages nomads to shift to organic production.

There is evidence that, besides being usually free from undesirable residues, the products from pastoralists are also appreciated for their high nutritional value and better taste. In Iran, milk and meat produced by nomads is regarded as a local specialty and is much preferred to that of animals raised by large industrial complexes. In addition to these material benefits of nomadic pastoralist products, there are significant immaterial values. Pastoralist breeds are part of the local heritage and contribute to local and regional identity, besides often being essential for traditional rituals. Despite this array of advantages, nomadic pastoralists currently continue to market their products generically and there is no awareness about the taste and health benefits of their animals among consumers, policy-makers and even themselves.

Nomads play an important role in sheep and goat production mainly because they keep $58.5 \%$ of the sheep and $39.7 \%$ of the goat population of Iran. Sheep and goat populations of Iran comprise 53.8 and 25 million head, which rank sixth and fifth in the world, respectively (FAO 2014). Nomadic systems in Iran are characterized by low population densities, movement of livestock between grazing areas (regions and provinces) in different seasons, weak linkages to markets and public services, and based on several multiple co-resident family units (clusters of two to five households staying together). The majority of the nomadic pastoralists do not have permanent settlements and consequently use mobile homes such as tents (Ansari-Renani 2015; AnsariRenani et al. 2013).

Growing demand for organic sheep and goat products will continue to be the main driver of nomadic livestock systems for domestic and export markets. At present, information regarding Iranian nomadic organic sheep and goat production systems is very limited. The objective of the present study was to describe the characteristics of and to evaluate potentials and conditions under which nomad pastoralists of southern Iran are able to produce different organic livestock products. Attempts were made to address constraints and shortcomings of the sustainable nomadic system in livestock organic production.

\section{Study area}

This study was undertaken in Kerman Province, Baft region in the southern part of Iran (Figure 1). Kerman Province is a highland region with $<250 \mathrm{~mm}$ annual rain. Summer is hot (up to $35^{\circ} \mathrm{C}$ ) and dry, and winter is moderate. Baft is a region in the south of Kerman province, $2270 \mathrm{~m}$ above sea level at latitude $29^{\circ} 17^{\prime} \mathrm{N}$ and longitude $56^{\circ} 36^{\prime} \mathrm{E}$. In this area, most nomad households belong to the Siahjel sub-tribe of the Raen tribe. This region has two main livestock breeds: the Raeini cashmere-producing goat and the carpet woolproducing Kermani sheep. Male Raeini goats have an average live weight of $35 \mathrm{~kg}$ and females $30 \mathrm{~kg}$. They produce on average $507 \mathrm{~g}$ of cashmere of different colours with averages of $56.5 \%$ down yield, $19.5-\mu \mathrm{m}$ fibre diameter and a staple length of $54.2 \mathrm{~mm}$ (Ansari-Renani et al. 2012). Kermani sheep produce on average $2.0 \mathrm{~kg}$ of wool with $70.0 \%$ efficiency, a staple length of $150 \mathrm{~mm}$ and a fibre diameter of $27 \mu \mathrm{m}$.

The nomads are completely dependent on livestock as a source of income. Nomad livestock production system is based on mixed herds with $89 \%$ of heads being goats, $8 \%$ sheep and $3 \%$ horses, mules, donkeys and sometimes camels used for transportation (Ansari-Renani et al. 2013). A typical nomad family would run some 250 goats, of which adult female goats (does) constitute $44 \%$; bucks, castrated adult males, male and female yearlings and male and female kids represent $8 \%, 5 \%$, $7 \%, 12 \%, 10 \%$ and $14 \%$ of the herd population, respectively.

\section{Methods}

Selection of nomad settlements and information gathering

A total of 30 nomad settlements were chosen at random within $\pm 20 \mathrm{~km}$ of Baft city in Kerman Province (Figure 1, Table 1). Information was gathered primarily through in-depth interviews with nomad men and women and field observations. Four periods of six to seven days of fieldwork were conducted within Baft region. Each interview lasted approximately three hours and consisted of about 50 predetermined questions. A structured questionnaire was completed for each individual family of settlement heads, including family composition and labour allocation structure, herd structure and management, housing, stocking rate, nutrition, feeding, watering, health, veterinary treatment, breeding, transportation, management practices, slaughtering, processing and reproduction. The responses to those questions were tallied, and the percentages of the various responses were calculated. Minimum, maximum, standard deviation (SD) and standard error values were measured using SAS package.

\section{Results and discussion}

Compared with conventional and organic systems (Table 2), nomadic sheep and goat production was characterized by natural breeding of locally adapted native breeds, extensive use of rangeland as a source of livestock feed, no use of prophylaxis, minimal allopathical treatments, protection of the environment, improved animal welfare and sustainable 


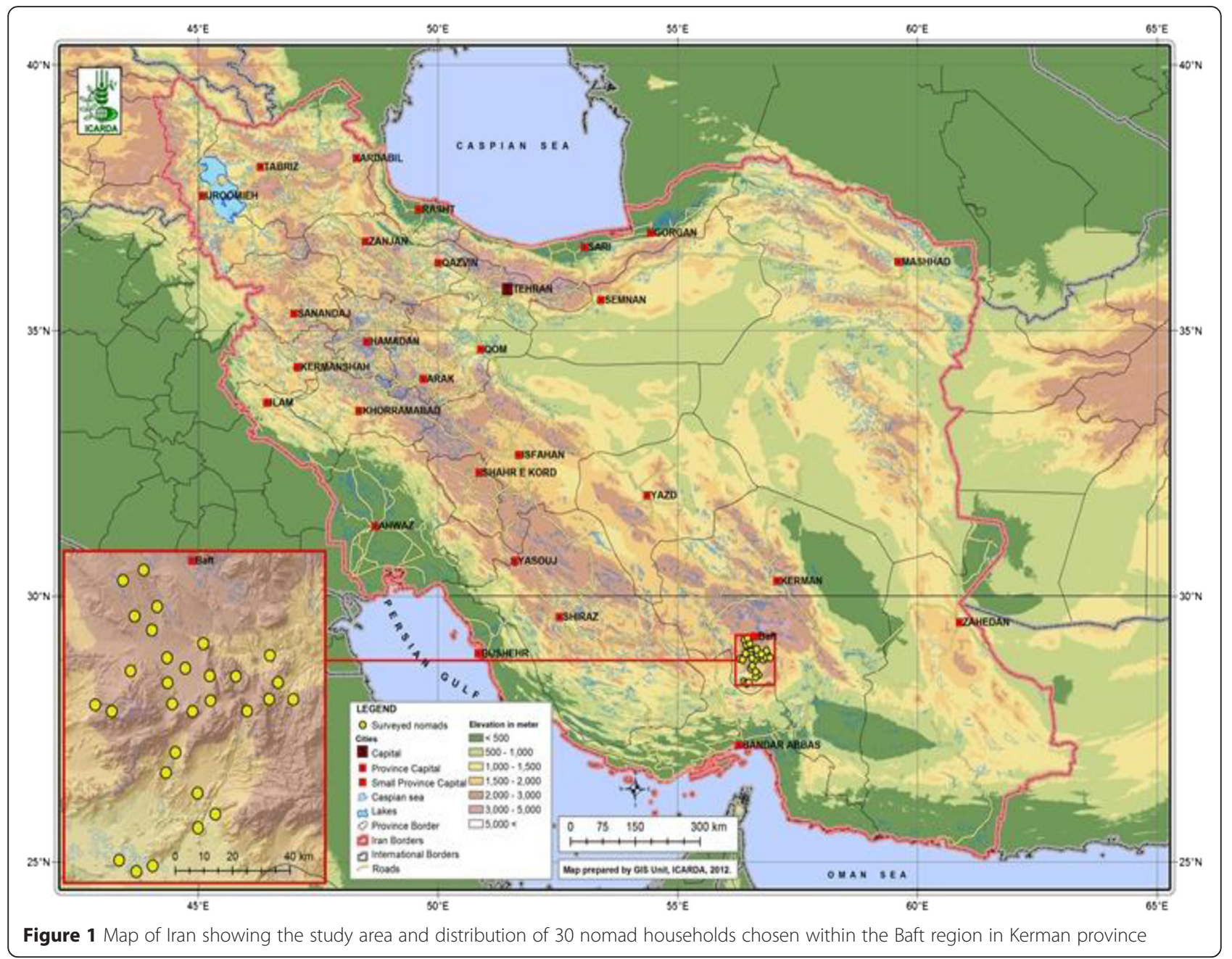

animal husbandry practices. In the nomadic system of sheep and goat production, one objective was to achieve animals' wellbeing through animal welfare-oriented husbandry and appropriate use. Curtailing freedom of movement, sensory deprivation and unsocial ways of husbandry; not allowing any contact with animals of the same species; or forcing too close a contact were not permitted in the nomadic farming system.

\section{Nomad sheep and goat breeds}

The livestock breeds kept by the nomads had unique characteristics, as they were subjected to selection criteria that were almost entirely different from those used in 'scientific animal breeding'. They were integral to their respective eco-systems and provided a host of environmental services. Taking droughts and hunger in their stride and acting as insurance, these breeds walk for miles in harsh terrain and seek out scattered, spiky, fibrous plants that survive in areas where crops could never be grown.

In organic farming, the breeding of small ruminants should be done by natural mating. Artificial insemination is allowed, but not embryo transfer, oestrus synchronization, etc. In the nomadic system, animal breeding was only by natural mating, and techniques such as artificial insemination, embryo transfer and oestrus synchronization were not popular among nomads. As a result of natural breeding, bucks and male yearlings were in disproportionate ratio (15\%) compared to adult and yearling females (56\%).

As industrial modes of livestock production are spreading, domestic animal diversity is in rapid decline. According to FAO, one third of all livestock breeds have either perished or are threatened with extinction, due to intensive selection for high production by means of artificial insemination and embryo transfer and spreading of a small number of genetically narrow high-performance breeds around the whole world. In this scenario, the main stewards of livestock genetic diversity are nomadic pastoralists and other 'small-scale livestock keepers' that raise animals under low-input conditions. Termed 'guardians of biological diversity' (FAO 2009), these people conserve biodiversity at the level of livestock breeds, vegetation, eco-systems and landscape. 
Table 1 Details of the 30 nomad cashmere-producing farms

\begin{tabular}{|c|c|c|c|c|c|}
\hline \multirow[t]{2}{*}{$\begin{array}{l}\text { Nomad } \\
\text { family }\end{array}$} & \multirow[t]{2}{*}{ Place of origin } & \multirow[t]{2}{*}{$\begin{array}{l}\text { Size of family } \\
\text { (persons) }\end{array}$} & \multicolumn{3}{|c|}{$\begin{array}{l}\text { Number of } \\
\text { animals (heads) }^{\text {a }}\end{array}$} \\
\hline & & & $\bar{G}$ & $S$ & $C$ \\
\hline 1 & Arzooeih & 7 & 225 & 40 & 30 \\
\hline 2 & Galoogiran & 5 & 142 & 40 & 41 \\
\hline 3 & Janat Abad & 6 & 251 & 33 & 35 \\
\hline 4 & Janat Abad & 8 & 306 & - & 50 \\
\hline 5 & Geloo Mahmoudabad & 9 & 323 & 4 & 70 \\
\hline 6 & Khobr & 7 & 280 & 21 & 50 \\
\hline 7 & Khobr & 4 & 200 & 10 & 30 \\
\hline 8 & Soltani-Baft & 6 & 373 & 150 & 20 \\
\hline 9 & Gelook - Baft & 9 & 315 & 33 & 15 \\
\hline 10 & Geloo Anjeer & 6 & 225 & 25 & 25 \\
\hline 11 & Se Chah Dehsard & 4 & 185 & - & 18 \\
\hline 12 & Dashtab - Baft & 5 & 179 & 47 & 45 \\
\hline 13 & Sanouheh Dashtab & 5 & 176 & 40 & 1 \\
\hline 14 & Dokoohe - Baft & 6 & 155 & 17 & 30 \\
\hline 15 & Dokoohe - Baft & 4 & 200 & - & 25 \\
\hline 16 & Zarab & 5 & 130 & - & 30 \\
\hline 17 & Sechah Dahsard & 5 & 356 & 3 & 25 \\
\hline 18 & Gelook - Baft & 4 & 303 & 53 & 15 \\
\hline 19 & Esmailabad - Baft & 5 & 208 & 58 & 20 \\
\hline 20 & Esmail Abad - Baft & 3 & 109 & 21 & 13 \\
\hline 21 & Esmailabad - Baft & 3 & 102 & 17 & 1 \\
\hline 22 & Geloo Mahmoudabad & 4 & 130 & 24 & 15 \\
\hline 23 & Geloodar Kooshki & 5 & 150 & - & 12 \\
\hline 24 & Godar Zarab & 3 & 83 & - & 15 \\
\hline 25 & Zarab & 6 & 219 & 20 & 20 \\
\hline 26 & Zarab & 3 & 140 & 50 & 13 \\
\hline 27 & Dahaneh Zardan & 4 & 155 & - & 20 \\
\hline 28 & Geloo Mahmoudabad & 5 & 120 & 15 & 15 \\
\hline 29 & Dehsalar & 5 & 286 & 106 & 30 \\
\hline 30 & Dehsalar & 5 & 153 & 15 & 15 \\
\hline
\end{tabular}

G, goats; S, sheep; C, chicken

\section{Husbandry management practices, transport and slaughtering}

Management of livestock among nomads was a social process, and they did their utmost for the wellbeing of their animal and to avoid animal cruelty of any kind. In the nomadic system, there were no tail ducking, dehorning and tethering (Table 3).

In organic systems, castration of male stock is allowed so as to keep traditional animal husbandry practices. In the nomadic areas, breeding management was difficult in mixed flocks of male and female animals, without male castration. All nomad livestock owners castrated the male kids and lambs at a very young age. The surgical technique of cutting the scrotum open with a knife and pulling the testicles was the common method of castration among nomads. They castrated their animals during the cool months of the spring and autumn, to reduce the chances of infection being spread by flies and other insects.

In organic farming, ruminants have to be kept in groups to meet their social needs; however, it is not defined how social needs can be fulfilled in farm conditions. Contrarily, nomads had well-defined social methods for keeping livestock under farming conditions. To keep ruminants in groups, $87 \%$ of nomad families stayed and move together with other families (Table 3). Furthermore, families staying and keeping their livestock together allowed nomads to herd adult and young animals separately as the social needs and feed requirements of different aninal age groups differ and require particular management practices.

The kidding period at the beginning of winter was at a season of lower temperatures and lower feed availability. Hence, animals were supplemented with limited amount of barley, and to avoid losses, at the end of autumn, most nomads migrated to warmer areas in the southern provinces adjacent to the Persian Gulf.

As a result of natural breeding and the high proportion of males to females in the nomadic flock, male breeding stock was kept and grazed separately during the breeding season. Bucks come into rut during the breeding season. Rut is characterized by a decrease in appetite, obsessive interest in the does and a strong heat. Nomads knew that when strong-smelling bucks are not separated from the does during breeding season, their scent will affect the milk. In organic farming, male breeding stock has to be kept in the farm. It is permissible to use conventionally-kept male breeding stock.

In organic farming, the animals have to be slaughtered in abattoirs which fulfil the regulations of organic farming and are certified (Leu 2014). Traditionally, the nomads consumed more milk in their diets than meat. In fact, they often express a dislike for killing and trading animals. Animals were sold to certified abattoirs or butchers directly either for cash needed for income or for culling unwanted livestock. Meat production was almost exclusively for sale. Home slaughtering for own consumption and sale to neighbours or relatives occurred only occasionally. The proportion of nomads buying animals was very low; the reason was that they usually depend on their existing animals to reproduce and increase their herd size.

The transport of livestock is not clearly defined in organic farming, but a stress-reduced loading, transporting and unloading of livestock without the use of allopathic tranquillizer, electrical shockers or similar tools is preferred. Nomad livestock movements between communal 
Table 2 Characteristics of conventional, organic and nomadic animal husbandry

\begin{tabular}{|c|c|c|c|}
\hline & Conventional $^{a}$ & Organic $(834 / 2007)^{\mathrm{a}}$ & Nomadic \\
\hline Breeds, origin & $\begin{array}{l}\text { Highly performing, special breeds } \\
\text { and cross-breeds according to } \\
\text { product aimed for }\end{array}$ & $\begin{array}{l}\text { Only animals reared in organic farms, diversity of } \\
\text { breeds, sometimes rare breeds, natural breeding }\end{array}$ & Native breed, locally adapted, natural breeding \\
\hline $\begin{array}{l}\text { Keeping } \\
\text { (buildings and } \\
\text { free runs) }\end{array}$ & $\begin{array}{l}\text { Animal protection laws } \\
\text { (requirements for keeping of } \\
\text { animal according to species) }\end{array}$ & $\begin{array}{l}\text { Special requirements for keeping animals } \\
\text { oriented toward animal welfare (stock density, } \\
\text { space, grazing, tiding, etc.) }\end{array}$ & $\begin{array}{l}\text { Animal are kept in rangeland, oriented } \\
\text { toward animal welfare }\end{array}$ \\
\hline Feeding & $\begin{array}{l}\text { According to current foodstuff } \\
\text { legislation (permitted food } \\
\text { additives such as enzymes and } \\
\text { synthetic amino acids) }\end{array}$ & $\begin{array}{l}\text { Foodstuffs produced as much as possible on site, } \\
\text { feeding rations according to animal welfare (e.g. } \\
\text { minimum use/parts of roughage) only specifically } \\
\text { permitted additives, no synthetic amino acids, no } \\
\text { genetically modified organisms }\end{array}$ & $\begin{array}{l}\text { Rangeland is considered the main source of } \\
\text { livestock nutrition, no synthetics, no GMOs, } \\
\text { no pesticides and chemical fertilizers, } \\
\text { livestock are not fed in stables or in restricted } \\
\text { areas but they move and graze freely in } \\
\text { extensive open grazing areas }\end{array}$ \\
\hline $\begin{array}{l}\text { Management } \\
\text { and treatment }\end{array}$ & $\begin{array}{l}\text { Managed breeding, if necessary } \\
\text { stable-wide prophylaxis, legally } \\
\text { required waiting periods } \\
\text { according to drug prescription law }\end{array}$ & $\begin{array}{l}\text { No prophylaxis (exception: legally required } \\
\text { vaccination), only three allopathical treatments per } \\
\text { year for long-lived animals (more than one year) } \\
\text { respectively one treatment for livestock, which is } \\
\text { not used more than one year; double the waiting } \\
\text { period after use of drugs, minimum } 48 \text { h. Restricted } \\
\text { interfering with the animal's integrity (no polling, } \\
\text { beak trimming, tail clipping, etc.) }\end{array}$ & $\begin{array}{l}\text { No prophylaxis (exception: legally required } \\
\text { vaccination), minimal allopathical treatments } \\
\text { per year, no tethering, polling and tail clipping }\end{array}$ \\
\hline Transport & Animal transport regulation & Animal transport regulation with short transport & $\begin{array}{l}\text { Animals are grazed by migration mainly, } \\
\text { some transportation by trucks }\end{array}$ \\
\hline
\end{tabular}

Adapted from Rahmann (2014)

grazing areas in different provinces are gradual, and animals are relocated by migration on foot which may take up to three to five days, depending on the distance covered. Sometimes, trucks were used to transport livestock between grazing areas in different Provinces.

\section{Feeding}

In organic farming, sheep and goats have to be fed with $100 \%$ organic feedstuff (EEC Regulation 2007). The statement that livestock has to be fed 'predominantly' with self-produced feedstuff is not specific enough. Fifty percent of organic feeds for ruminants can be purchased from other organic farms. Comparatively, in this study, rangeland was considered the main source $(85 \%)$ of sheep and goat nutrition of nomad farms without any use of chemicals such as fertilizers and pesticides

Table 3 Percentage of nomad herds moving together and adopting different management practices

\begin{tabular}{ll}
\hline Items & Percentage \\
\hline Management practices & 0 \\
Dehorning & 0 \\
Tethering & 0 \\
Shortening of tails & 100 \\
Castration of male lambs and kids & \\
Families moving together & 13 \\
Single & 87 \\
Two or more & \\
\hline
\end{tabular}

(Figure 2) while other sources of feed such as crop stubble composed only a small portion (15\%) (Table 4). The ratio between the high price of feed inputs and lower price of livestock products provides insufficient incentives for the nomads to purchase synthetic chemical inputs for developing intensive production systems.

In organic farming, it is not permitted to use anything produced using genetically modified organisms (GMOs) or derivatives. This includes feed for livestock. There are permissible minerals, vitamins and pro-vitamins for animal feed, and artificially produced vitamins may not be used for ruminants. In the nomadic traditional feeding management practice, all farms did not use minerals,

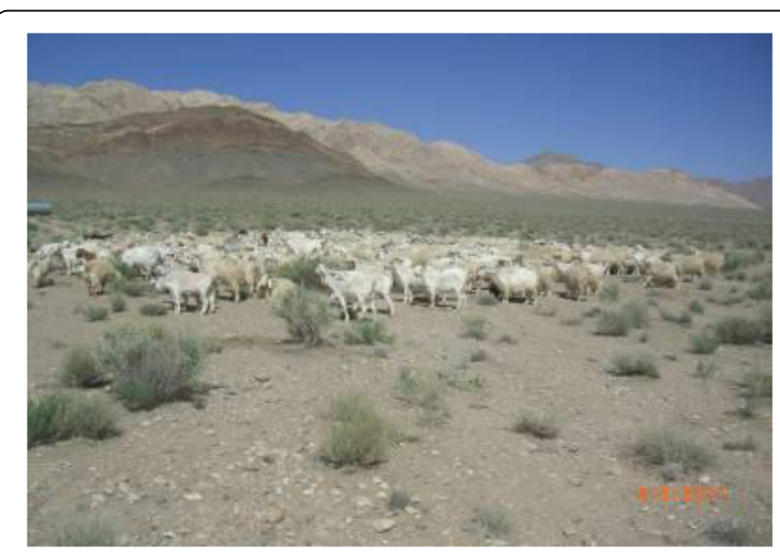

Figure 2 Rangeland is considered the main source of nomad sheep and goat nutrition of southern Iran 
Table 4 Percentage of nomad farms using different chemicals, sources of feed, type of grazing land and feeding method

\begin{tabular}{ll}
\hline Items & Percentage \\
\hline Farms using chemicals & 0 \\
Fertilizers & 0 \\
Pesticides & 0 \\
Others & \\
Source of feed & 85 \\
Rangeland & 15 \\
Stubbles, agriculture residues, etc. & 0 \\
Use of genetically modified organisms (GMO) & 0 \\
GMO derivatives & 0 \\
Minerals, vitamins and pro-vitamins & 100 \\
Source of lamb and kid feed & 0 \\
Colostrum and maternal milk & \\
Powdered milk & 38 \\
Type of grazing land & 23 \\
Open grassland & 39 \\
Tree covered & 100 \\
Bush/shrub and stone covered & 0 \\
Feeding method & \\
Free-range grazing & \\
\hline
\end{tabular}

vitamins, pro-vitamins and GMOs for animal feed, as the cost of such inputs is too high (Table 4).

In organic farming, a feeding system which leads to anaemic conditions in sheep and goats is prohibited and considered as animal cruelty. To avoid such conditions, as feeding management practice, $23 \%$ of nomad farms preferred tree-covered grazing areas (Figure 3 ) which include wild oak trees, as the nutritive value of leaves that

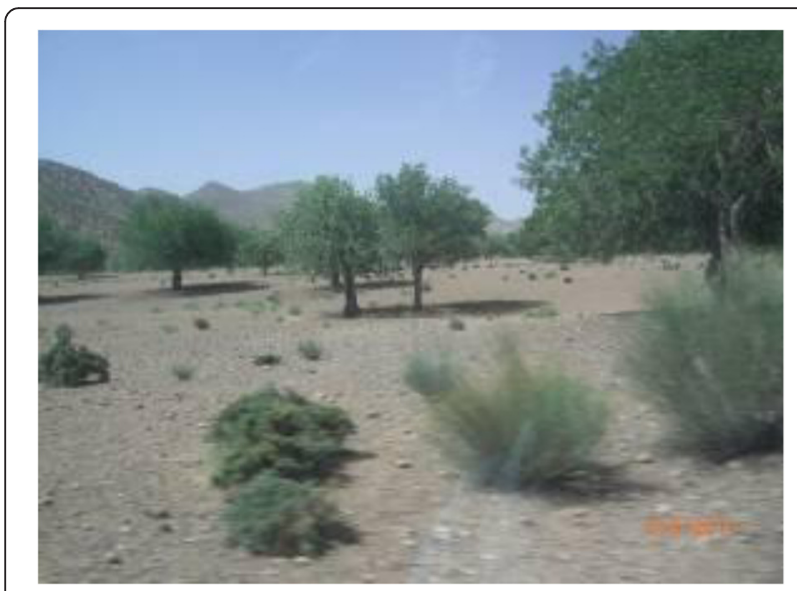

Figure 3 Tree-covered grazing land in southern Iran suitable for grazing livestock are rich in iron, sulphur and copper consumed by animals complements the grass very well. Thirty-eight percent and $39 \%$ of nomad farms used open grassland, bush/shrub and stone-covered rangeland, respectively (Table 4).

In focus group discussions, nomad herders frequently emphasized that the diversity of plant species consumed was responsible for the superior taste and healthiness of sheep and goat milk and meat. Most of these plants also have medicinal value. The local knowledge of the nomad pastoralist communities sees a connection between the dietary composition of livestock feed and the nutritional value of livestock products.

Nomadic sheep and goat breeds were social animals in the true sense, living in a and flock, responding to the voice of their keepers. By means of such breeds of livestock that are co-evolved with their eco-system, nomads were in a position to use the dispersed and extremely bio-diverse natural vegetation of drylands and mountainous areas into a range of high-value delicious organic food including meat and milk, as well as a range of other organic products such as fibre, fertilizer and hides. They did this without leaving any carbon footprint, as their animals forage for themselves and no energy is expended to grow or transport feed to them.

On many organic farms, kids and lambs receive only colostrum milk and subsequently powdered milk. The young stock does not suckle and receive natural milk because the organic milk is very valuable and expensive (Rahmann 2002). Even skimmed powdered cow milk can be used as long as it has an organic label. In the nomadic system there was no early weaning system, contrary to intensive and organic sheep and goat systems of production in which early weaning of lambs and kids is practised and all the milk and milk products are consumed by humans.In all nomad farms, kids and lambs suckled their mothers for 45 days and received only maternal milk (Table 4). When young animals were still nursing, the flock returned to the tent at least once each day to allow the young to nurse.

\section{Animal health and veterinary treatments}

In organic farming, the principle of animal health is prevention rather than curing/treating. In the nomadic system, as a preventive practice, newborn and young animals were often kept together at the tent with the nomad women and children until they were old enough to go out to pasture with the flock.Animals that were diseased were likewise kept at the family tent, effectively isolated from the flock so chances that infection will spread throughout the flock are thus reduced.

Robust, adapted and disease-tolerant livestock ensure fit and healthy animals. Nomad breeds were considered to fulfil these targets. These were indigenous breeds 


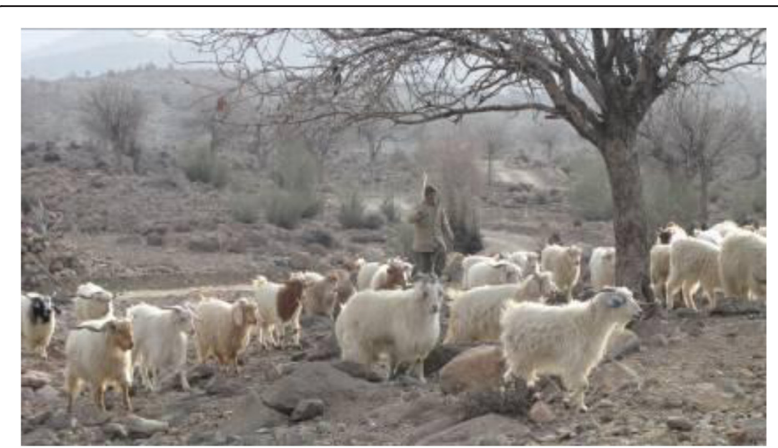

Figure 4 Nomads migrate to warmer areas of southern provinces adjacent to the Persian Gulf in the beginning of autumn

typical of a specific region, adapted to the local environmental conditions and retaining the pattern for centuries.

Many of the nomads' animal management practices had a direct positive impact on the incidence of livestock diseases. Some of the most significant practices include reproduction management, the isolation of diseased animals, grazing and seasonal migration patterns. Nomad herders believed that by herding more than one species, the risk of livestock losses was buffered, whether losses were due to diseases or extreme environmental conditions. They emphasized that the annual migrations that most Raen nomads undertake as well as the extensive grazing patterns of the herd help to lower the incidence of diseases, including internal parasites.

Nomads highlighted that their indigenous technical knowledge and medicinal plants for health care were effective substitutes for allopathic medicines, giving them an advantage in organic livestock production. The indigenous knowledge of nomads may provide an effective option for veterinary care through proper validation, as also the negligible use of agro-chemicals, especially in drylands and hilly nomadic regions provides a favourable environment for organic livestock production.

Nomads knew that infections of the udder can be spread from one animal to another during milking and

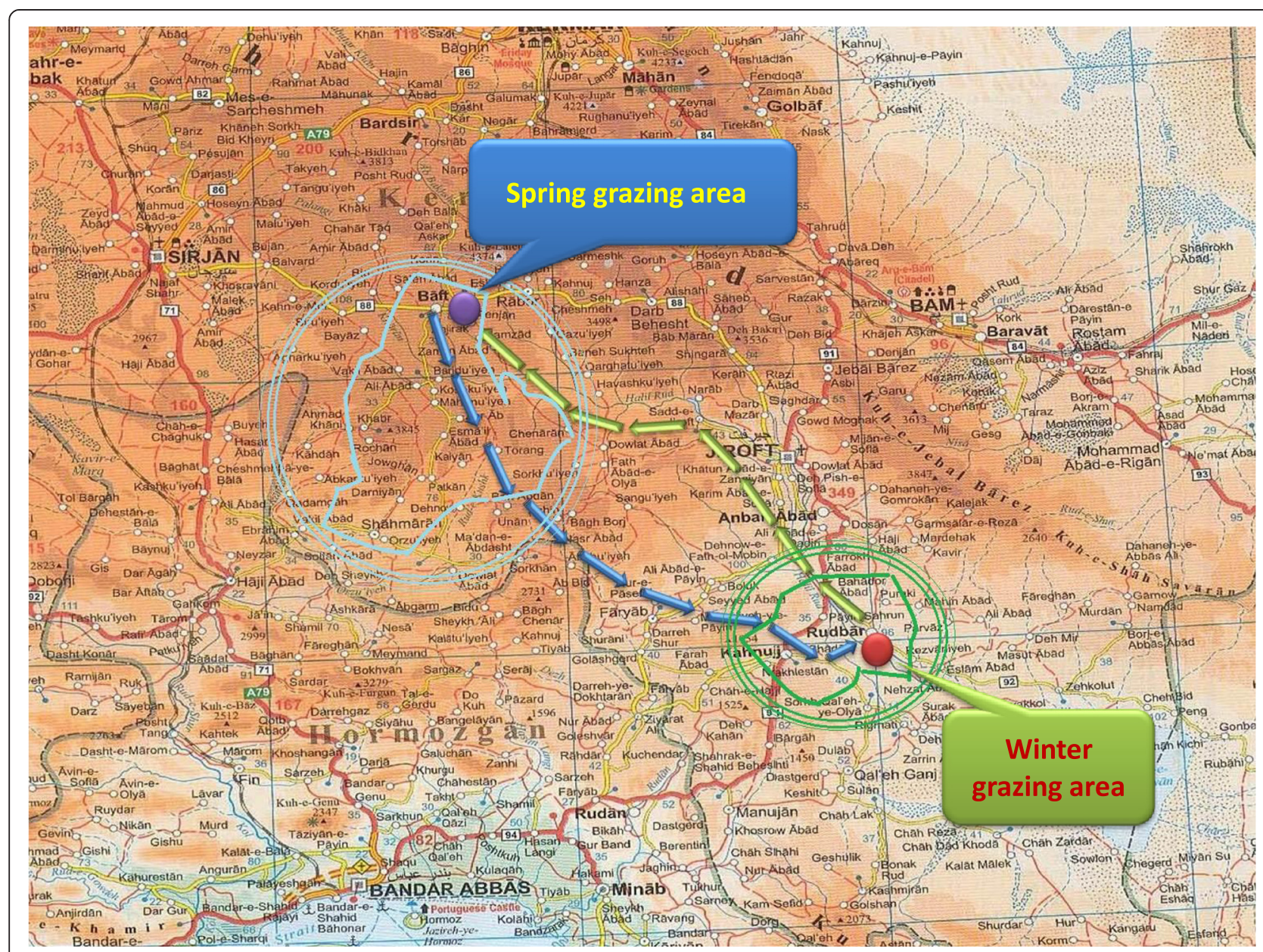

Figure 5 Map of south Iran showing the spring and winter grazing areas in Kerman (Baft region) and Hormozgan (Roodan region) provinces near the Persian Gulf in blue and green colours, respectively 
washed their hands with water between milking animals. Both men and women helped at animal births. Women often explained that they were better than men at this since they have smaller hands, which is good for repositioning the foetus within the birth canal.

\section{Housing and stocking rate}

Tethering of livestock is prohibited in organic farming. Basically, there was no tethering of any kind of livestock among nomads. When nomad livestock returned from grazing, adult and young animals were penned separately near the tent in circular-shaped pens made up of wood, fenced overnight and milked in the morning before being taken out for grazing.

In organic farming, it is obligatory that ruminants should graze on pastures ('free-range') and not fed in stables as long as the animal, weather and pasture conditions are suitable. If grazing is not possible, a permanently accessible open-air run is obligatory. Free-moving stables with permanent access to open-air runs are the principle of ruminant keeping. Only with permanent summer pasture grazing is an outdoor run not necessary, as long as the animals are not tethered.

The nomad livestock were not fed in stables or in restricted areas, but moved and grazed freely in extensive open grazing areas. Nomad families used the northern highland rangelands in spring and summer for grazing and migrated to the warmer southern Persian Gulf provinces in autumn and winter (Figures 4 and 5). The nomadic pastoralists had no fixed homesteads and covered great distances with their livestock following pasture availability throughout the seasons. The transhumant pastoralists followed a regular seasonal movement between set areas. Their movement was vertical where pastures at high altitudes are used in summer and pastures in the lowlands are used in winter or horizontal in the surroundings. Consequently, the livestock density (stocking rate) in Baft varied throughout the year, with the highest number of livestock and people in summer.

\section{Conclusion}

The ideology behind principles and standards of organic animal husbandry is not new to the nomadic farming system of Iran, whose community have practiced animal welfare and animal natural rearing systems since ancient times. A country rich in indigenous animal genetic resources like Iran is very much suitable for adopting this farming system. Moreover, the nomadic farming system with well-diversified livestock populations in terms of species and breeds is ideal for organic livestock production. Nomad breeds being less susceptible to diseases and stress need less allopathic medicines/antibiotics. Besides, limited external input use, including for animal production and maximum on-farm reliance brings the nomadic system nearer to organic systems. The nomadic sheep and goat production system being largely extensive, animal welfare is not much compromised compared to intensive or conventional type of animal production.

Although the nomadic type of livestockkeeping provides an excellent and 'green' alternative to industrial production, nomad pastoralists need to overcome some challenges and harness strengths and opportunities, while developing their capacity in terms of knowledge, skills, infrastructure, animal feeding, hygiene, sanitation, disease control and assured certified supply chain required for organic livestock production.

Nomad farmers need to be oriented and educated about the organic standards and how to overcome the risks they might face in adoption of organic livestock standards. The livestock advisors should be trained and skilled in providing services in livestock management and permitted therapies in organic rearing systems. Research on the locally adaptable management and disease-preventive measures needs to be emphasized by the government and organic-promoting agencies as well as NGOs. The potential needs to be recognized of Iranian nomad farmers to meet the requirements of organic livestock product demand, not only locally but also globally in the near future. Organic livestock production can be encouraged through research and development efforts, including establishment of model organic livestock farms, processing units, traceability tools and capacity-building measures.

Converting extensive, range-based nomadic system to organic production could become economically attractive, if price premiums could be captured for organic meat and livestock products. Development of business models will definitely attract commercial interests and ensure that vulnerable nomadic communities receive attractive returns for their untapped treasure of organic principles. Systematic studies need to validate the animal husbandry practices of nomads with respect to organic certification, so that revision or improvement can be made wherever necessary. In this way, organic livestock products will have considerable potential for high-value niche markets.

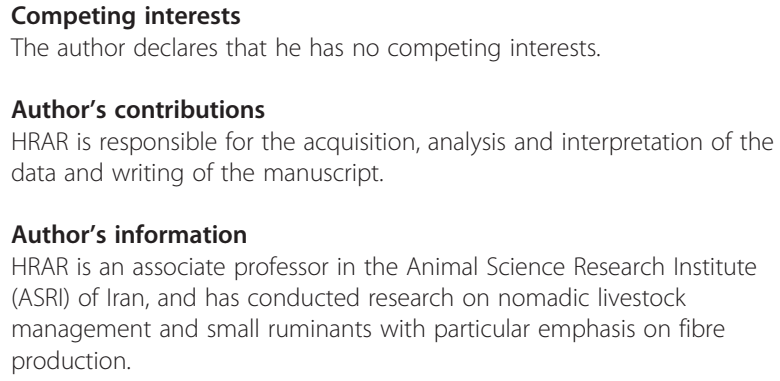

Received: 30 October 2015 Accepted: 13 April 2016

Published online: 03 May 2016 


\section{References}

Ak, I., and M. Koyuncu. 2002. Organic meat and milk production by pastoralists from small ruminant in Turkey. EAAP publication, No. 106.

Ansari-Renani, H.R. 2015. Cashmere production, harvesting, marketing and processing by nomads of Iran - A review. Pastoralism: Research, Policy and Practice 5: 18

Ansari-Renani, H.R., J.P. Mueller, B. Rischkowsky, S.M. Seyed Momen, and S. Moradi. 2013. Nomadic pastoralism in southern Iran. Pastoralism: Research, Policy and Practice 3: 11.

Ansari-Renani, H.R., J.P. Mueller, B. Rischkowsky, S.M. Seyed Momen, O. Alipour, M. Ehsani, and S. Moradi. 2012. Cashmere quality of Raeini goats kept by nomads in Iran. Small Ruminant Research 104: 10-16.

Aurousseau, B., D. Bauchart, E. Calichon, D. Micol, and A. Priolo. 2004. Effect of grass or concentrate feeding systems and rate of growth on triglyceride and phospholipid and their fatty acids in the M. longissimus thoracis of lambs. Meat Science 66: 531-541.

Ben Kheder, M. 2001. Mediterranean organic agriculture course, organic vegetable production. Bari: Mediterranean Agronomic Institute of Bari.

EEC (European Economic Commission). 2007. Regulation (EEC) No. 834/2007. Bruxelles, Belgium.

FiBL (Research Institute of Organic Agriculture) and IFOAM (International Federation of Organic Agriculture Movement). 2013. The World of Organic Agriculture 2013. Available: https://www.fibl.org/fileadmin/documents/shop/ 1606-organic-world-2013.pdf Accessed on 10/06/2014

Fisher, A.V., M. Enser, R.L. Richardson, J.D. Wood, G.R. Nute, E. Kurt, L.A. Sinclair, and R.G. Wilkinson. 2000. Fatty acid composition and eating quality of lamb types derived from four diverse breed X production systems. Meat Science 55: 141-147

Food and Agriculture Organization of the United Nations. 2009. www.FAOSTAT. com.

Food and Agriculture Organization of the United Nations. 2014. www.FAOSTAT.com.

Herman, G. A., and M. Steidle. 2014. 2nd International Conference on Trade and Market Development of Organic Producers. Iran Organic Association. Tehran, Iran

IFOAM (International Federation of Organic Agriculture Movement). 2005. The IFOAM norms for organic production and processing. Bonn: IFOAM.

Jaffee, D., and P.H. Howard. 2010. Corporate co-optation of organic and fair trade standards. Agriculture and Human Values 27(4): 387-399.

Leroux, J., M. Fouchet, and A. Haegrlin. 2009. Elevage bio: des cahiers des charges francais a la reglementation europeenne. INRA Productions Animales 22: 151-160.

Leu, A. 2014. Achieving food security, climate change adaptation with high yielding organic agriculture in Iran. Second international conference on trade and market development of organic producers. Iran Organic Association. Tehran, Iran.

Rahmann, G. 2002. The standards, regulations and legislation required for organic ruminant keeping in the European Union. EAAP Publication 106: 15-26.

Rahmann, G. 2014. 2nd International Conference on Trade and Market Development of Organic Producers. Tehran: Iran. Organic sheep and goat farming.

Sante-Lhoutellier, V., E. Engel, and P. Gatellier. 2008. Assessment of the influence of diet on lamb meat oxidation. Food Chemistry 109: 573-579.

Schleenbecker, R., and U. Hamm. 2013. Consumers' perception of organic product characteristics. A review. Appetite 71(1): 420-429.

Steidle, M., and G. Herman. 2014. 2nd International Conference on Trade and Market Development of Organic Producers. Tehran: Iran. How to best design an organic guarantee system for global market access.

Znaidi, A. 2001. Sheep and goat organic meat production in the Mediterranean region, DSPU thesis in Mediterranean Organic Agriculture. Bari: Mediterranean Agronomic Institute of Bari.

\section{Submit your manuscript to a SpringerOpen ${ }^{\circ}$ journal and benefit from:}

- Convenient online submission

- Rigorous peer review

- Immediate publication on acceptance

- Open access: articles freely available online

- High visibility within the field

- Retaining the copyright to your article

Submit your next manuscript at $\gg$ springeropen.com 